\title{
What's In It For Me?
}

\section{Personal Benefits Obtained by CEOs Whose Firms Are Acquired}

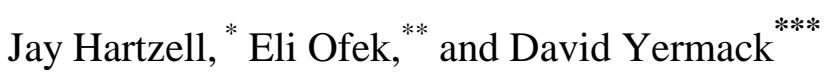 \\ Department of Finance \\ Stern School of Business \\ New York University \\ 44 West $4^{\text {th }}$ Street, Suite 9-190 \\ New York, NY 10012
}

July $2000 \dagger$

\begin{abstract}
We study benefits received by target company CEOs in completed mergers and acquisitions. These executives obtain wealth increases with a median of $\$ 4$ to $\$ 5$ million and a mean of $\$ 8$ to $\$ 11$ million, roughly in line with the permanent income streams that they sacrifice. CEOs receive lower financial gains from those transactions in which they become executives of the buyer, suggesting that tradeoffs exist between the financial and career-related benefits they extract. Regression estimates suggest that target shareholders receive lower acquisition premia in transactions that involve extraordinary personal treatment of the CEO.
\end{abstract}

\footnotetext{
*3hartzel@stern.nyu.edu. Phone: (212) 998-0359. Fax: (212) 995-4233.

***eofek@stern.nyu.edu. Phone: (212) 998-0356. Fax: (212) 995-4233.

**** dyermack@stern.nyu.edu. Phone: (212) 998-0357. Fax: (212) 995-4220.
}

\footnotetext{
${ }^{\dagger}$ We would like to thank seminar participants (especially our discussant, Paul Halpern) at the JFE/Tuck Center for Corporate Governance conference for their helpful comments.
} 


\section{What's In It For Me?}

\section{Personal Benefits Obtained by CEOs Whose Firms Are Acquired}

\section{Introduction}

Negotiations in mergers and acquisitions often hinge on "social issues" involving top managers. Self-interested executives bargain not only over the price to be paid to target shareholders, but also over such items as who will occupy the CEO position in the merged company, who will sit on the board of directors, the location of headquarters, whether the company name will change, and especially, executive compensation. The news media has reported the collapse of numerous high-profile merger discussions because of managers' inability to reach compromises over these private benefits, indicating that severe agency problems can prevent economically beneficial transactions from occurring. ${ }^{1}$ Further stories have reported elaborate, lucrative packages of personal benefits negotiated by target CEOs as conditions for agreeing to their firms' acquisition.

${ }^{1}$ Salpukis (1999) describes how the proposed acquisition of Texaco Inc. by Chevron Corp. fell through because Chevron's CEO “was not willing to share power with" his Texaco counterpart. Burton and Tanouye (1998) discuss the failure of the merger of American Home Products Corp. and Monsanto Co. due to managerial disagreements that "ranged from who should be assigned to corporate headquarters to compensation for top executives." The announcement of this deal's collapse caused a one-day \$14 billion decline in the companies' joint market capitalization. Lipin (1996) provides several additional examples.

${ }^{2}$ For example, Hechinger (1999) reports that as part of his company's merger agreement with Fleet Financial Group, the CEO of BankBoston Corp. extracted a promise that he would become CEO of the buyer at the end of 2001 unless 80 percent of the board objected at that time to his appointment. If so, the company would be required to pay $\$ 15$ million to the CEO's charitable foundation. 
The notion that executives extract private benefits from managing the firm is common in the corporate finance literature. Many theoretical papers use private benefits of control as a modeling assumption; for two recent examples, see Fluck (1999) and Berkovitch and Israel (1996). These private benefits can cause agency problems that reduce the value of the firm, and the market for corporate control provides a vital mechanism for mitigating these problems. The takeover market of the 1980s featured a high incidence of hostile acquisitions characterized as discipline of incumbent management (see, e.g., Mørck, Shleifer, and Vishny, 1988). In contrast, regulatory changes in the market for corporate control caused the 1990 s to have few hostile acquisitions, as shown by Schwert (2000). Given the diminished disciplinary power of the takeover market, we investigate the question: If managers obtain private benefits of control, under what circumstances will they surrender them in a friendly merger?

We study a sample of several hundred completed U.S. acquisitions in the late 1990s, documenting the benefits, financial and otherwise, received from the transactions by the CEOs of the target companies. We collect information on such variables as stock and option appreciation, golden parachute payments, additional cash payments made because of the transaction, the CEO's position in the new firm, and the composition of the new board of directors. For those executives that remain involved with the acquiror as either an officer or director, we track their change in executive compensation and their position for three years following the transaction.

We expect that target CEOs will attempt to extract large benefits from merger transactions to compensate for the losses of compensation, power, and prestige that occur when they agree to sell their companies. These benefits might take the form of either increased financial wealth or attractive positions in the management team of the buyer. In addition, we 
expect that CEOs might be willing to compromise the interests of their own shareholders in pursuit of these benefits, possibly negotiating less favorable acquisition terms in those deals in which they personally fare well.

Our empirical results provide benchmarks with which to measure the gains obtained by target CEOs whose firms are acquired, while also providing some evidence of agency problems arising in the negotiation of mergers and acquisitions. The CEOs in our sample obtain total financial gains with a median value of approximately $\$ 4$ to $\$ 5$ million and a mean of $\$ 8$ to $\$ 11$ million. While the distribution exhibits an upper tail that includes truly large windfalls for some target CEOs, for most executives these monetary benefits appear roughly in line with the permanent income streams that they lose from the disappearance of their prior jobs.

We find that CEOs receive lower financial benefits in those transactions in which they become executives of the buyer, suggesting that tradeoffs exist between the financial and employment benefits that selling CEOs extract from the sale of their firms. However, these career-related gains may be largely illusory. While slightly more than half of the target CEOs accept managerial positions in the buyer, but only a small minority take leadership posts such as CEO or chief operating officer. Job security is quite low for these former CEOs, with postmerger turnover rates in the neighborhood of $20 \%$ to $30 \%$ annually.

Finally, we present regression estimates that provide some evidence indicating that target CEOs negotiate lower acquisition premia for their own shareholders in transactions that involve extraordinary personal treatment of the CEO. These transactions are characterized by special payments to the $\mathrm{CEO}$ at the time of the merger, as well as high-ranking managerial posts in the buyer and membership on the buyer's board of directors. 
Our study complements the previous literature in two ways. First, by analyzing completed mergers we examine managerial incentives at a later stage of the acquisition process than in most prior papers, which have generally focused on the probability of firms becoming targets and the likelihood of managerial resistance to offers. Second, where the previous work often characterized the conditions under which management was forced to give up control, we use a more recent sample to determine the circumstances under which management voluntarily agrees to forego the benefits of control.

The remaining sections of the paper are organized as follows. Section 2 reviews related literature about managerial characteristics and corporate control activity. Section 3 describes our sample selection and data gathering. Section 4 analyzes the gains received by target CEOs as a result of the acquisitions. Section 5 concludes.

\section{Literature review}

Our investigation of the benefits received by target CEOs in completed mergers complements a previous literature studying managerial incentives in corporate control activity. Much of the prior literature documents target management's ability at various stages of the acquisition process to take actions in their own interests rather than those of shareholders. For example, a firm's attractiveness as a takeover candidate may be decreasing in managerial ownership, due to management's reluctance to give up their positions or control of the firm (e.g., Mikkelson and Partch, 1989). Conditional on receiving an offer, managers may resist the proposed combination in order to protect their personal benefits at the expense of shareholders' wealth (e.g., Cotter and Zenner, 1994). 
Personal stock ownership represents one clear source of potential variation in target managers' attitudes toward selling their firms. Stulz (1988) argues that higher managerial ownership results in two competing effects. First, firms with higher ownership are less likely to be subject to an acquisition attempt due to the CEO's voting control. Second, conditional on an attempt being made, firms with higher managerial ownership are expected to receive a higher price due to the CEO's bargaining power. Empirical evidence has been largely consistent with these implications. For example, Song and Walkling (1993) find that acquisition targets have lower ownership than their industry's average, or corresponding matching firms. For attempts that are eventually successful, managerial ownership is positively related to abnormal returns on the target's stock over the period from announcement through outcome. Mikkelson and Partch (1989) find no relation between the likelihood of a successful acquisition and management's control of the target. This lack of a relation, however, is due to two offsetting effects. The probability of receiving a takeover offer is decreasing in management ownership, but the probability that an offer (if made) leads to a change in control increases with management ownership.

Related work has documented relations between variables other than management ownership and the likelihood of takeovers and acquisitions. For example, Shivdasani (1993) argues that the board of directors acts as a substitute mechanism for corporate control, while unaffiliated blockholding acts as a complementary mechanism. He finds that the likelihood of a hostile takeover attempt is decreasing (increasing) in the ownership stake of the outside directors (affiliated blockholders). Aside from governance and incentive variables, many studies have shown a relation between firm performance and the likelihood of being an acquisition target 
(e.g., Palepu, 1986).

Once an offer has been made, management's response depends on the incentive mechanisms in place. Cotter and Zenner (1994) and Walkling and Long (1984) argue that management's resistance to tender offers appears driven by concern over its own interests rather than those of shareholders. Both studies document that management resistance is negatively related to the change in managerial wealth, an effect attributed by the former study to the change in wealth due to managerial share ownership. Further, Cotter and Zenner (1994) show that management gains on average from resisting tender offers (while shareholders do not), and that the probability of a successful offer is increasing in the change in managerial wealth.

Hadlock, Houston and Ryngaert (1999) argue that managers' incentive to act in their own interests also affects the likelihood of being acquired. They show that for a sample of bank acquisitions, banks with higher ownership are less likely to be acquired. This result is especially strong for observations where the target managers leave the firm following the acquisition. They interpret the results as consistent with the hypothesis that the degree of managerial entrenchment is an important determinant of the probability that a bank is acquired.

Hadlock at al. (1999), Agrawal and Walkling (1994), and Martin and McConnell (1991) document high rates of managerial turnover for target firms following corporate control activity. Hadlock et al. find that $53.6 \%$ of their sample's top executives leave the banking organizations within two years of the date the merger agreement is finalized. Agrawal and Walkling (1994) calculate the retention and dismissal rates of CEOs for a set of firms receiving takeover bids. They find that only $45 \%$ of the target CEOs are retained one year after the bid. Successful bids result in even larger departure rates; for this subsample, $65 \%$ of the CEOs are not employed as 
senior executives in any public corporation one year after the bid. Martin and McConnell focus on turnover of top managers of targets of successful tender offers. They find a turnover rate of $41.9 \%$ for the target's top manager in the year following the takeover, and 19\% during the second post-turnover year. They classify takeovers in which the target's top executive leaves the firm as disciplinary. They then show that disciplinary takeovers are associated with poor performance by the target prior to the tender offer, while non-disciplinary takeovers are not. Additionally, gains to both bidders and targets are independent of the type of takeover (disciplinary or nondisciplinary).

Agrawal and Walkling (1994) and Harford (2000) consider the effects of takeover bids on management and directors in terms of Fama's (1980) notion of "ex post settling up." Agrawal and Walkling consider the effects of takeover bids on target-firm CEOs from 1980 to 1986. Consistent with ex post settling up, they find that post-bid changes in compensation are negatively related to pre-bid abnormal compensation. They interpret this as consistent with the view that the labor market uses information produced by the takeover process to discipline managers. Harford finds evidence consistent with directors also experiencing ex post settling up following takeover bids occurring from 1988 through 1991. He shows that outside directors generally fare worse (financially) than inside directors following the bid, and the outcome is related to both pre-bid performance and the target's reception of the offer. Specifically, outside directors of poorly-performing firms fare worse in the directorial labor market, especially if the target rebuffs the offer. If the firm accepts the offer, the directors' losses are mitigated.

Mørck, Shleifer, and Vishny (1988) connect the nature of the transaction to its purpose, arguing that disciplinary takeovers typically appear to be hostile in nature, while mergers for 
synergistic reasons tend to be friendly. They find that characteristics other than financial incentives of target managers differ across these two types of deals. Segmenting acquisitions into friendly and hostile, they document a relation between managerial ownership and the type of acquisition. Compared to hostile mergers, friendly acquisitions are associated with greater stock ownership by directors and officers, and increased incidence of founding family members managing the target firm. Large managerial ownership appears to encourage friendly acquisitions, but not significantly discourage hostile ones. The performance of friendly targets is basically indistinguishable from that of non-targets in their sample, while hostile-takeover targets are associated with poor relative performance. Mørck et al. (p. 104) interpret their evidence as "consistent with the view that hostile targets and friendly targets are very different types of companies."

\section{Sample selection and data description}

We analyze a sample of 311 transactions identified from the mergers and acquisitions database of Securities Data Company. We begin with all completed U.S. mergers with announcement dates between January 1, 1995, and December 31, 1997. We require that (i) both firms be publicly traded and listed on the Center for Research in Securities Prices database; (ii) both have market capitalizations exceeding $\$ 100$ million four weeks prior to the announcement date; (iii) the buyer purchase at least 90 percent ownership of the target; and (iv) the ratio of the two firms' market capitalizations lies within the range of 0.10 to 10.00 , to rule out transactions with extreme size disparities. These screens yield a candidate sample of 320 deals. We drop eight observations in which the acquiror already held a dominant ownership position in the 
target, and one transaction involving a Canadian firm that was not required to meet the Securities and Exchange Commission's filing requirements.

We focus our data gathering on the remaining 311 target companies and their CEOs. For each of these, we attempt to obtain information from three SEC filings: (i) the Proxy Statement, Form 10-K or similar document containing ownership and compensation data in advance of the last annual meeting before the acquisition announcement; (ii) the Proxy Statement, Form S-4, or other document (if any) filed in connection with the transaction; and (iii) the first Proxy Statement of the acquiring company filed after the merger becomes effective. Our final sample for regression analysis includes information about 239 target CEOs, meaning that we have missing values for at least one variable for 72 out of 311 companies, or 23 percent. The main sources of missing values are variables related to golden parachutes and related merger payments (missing for 39 CEOs), stock and option ownership data (missing for 26 CEOs), and cash compensation data (missing for 22 CEOs).

Table 1 presents descriptive statistics about the CEOs in our sample companies. The typical CEO is about 54 years old, with median stock and option ownership of 0.8 percent and 1.1 percent of the company's shares outstanding, respectively (mean values are slightly higher). The median salary + bonus cash compensation for CEOs in the year prior to the acquisition is about $\$ 521,000$ (mean $\$ 798,000$ ). Many of the CEOs share power with at least one other top executive: in 30.5 percent of the firms someone else holds the title of chairman of the board, while in 28.5 of the sample some other executive serves as president of the company. We are unable to calculate statistics about the tenure in office of many CEOs, since a significant proportion of the sample companies disclose only that their CEOs have served for more than five 
years. Our sample is almost equally split between CEOs who have served less than five years and five or more years.

Information about our sample of transactions appears in Table 2. The median target firm has market capitalization of $\$ 386$ million (mean $\$ 1.28$ billion), measured one month prior to the date of the first offer made by the buyer. The ratio of the target's market cap divided by the buyer's has a median of 0.317 (mean of 0.442 ), indicating that some size disparity exists between the two companies in most of our transactions, but not to a severe extent. Just 2.6 percent of our transactions begin with unsolicited bids, according to SDC. We measure the takeover premium to target shareholders using information from both SDC and CRSP. SDC reports a median premium of 30.4 percent (mean of 34.8 percent) over the four weeks prior to the transaction announcement. This statistic assumes that the deal will ultimately close according to the terms announced in the merger agreement. If the consideration paid to target shareholders is stock in the buyer, the SDC premium uses a pre-announcement value of the buyer's stock price. We calculate an alternative measure of the takeover premium from the CRSP database, measuring the stock's run-up over the 20 days prior to the announcement, and we find lower premia with a median of 21.1 percent (mean of 22.7 percent). These smaller gains in target equity value might capture a variety of effects, including a post-announcement decline in the buyer's stock price, skepticism that the deal will be completed according to its announced terms, or the time value of money if the approval process is expected to be lengthy.

\section{Benefits received by target CEOs}

CEOs of acquired companies can potentially obtain benefits from a variety of sources, 
both financial and otherwise. Table 3 presents information about the wealth increases experienced by target CEOs as well as their post-merger role in the governance of the buyer company. We estimate that CEOs earn a median of approximately $\$ 4$ to $\$ 5$ million in increased wealth (mean of $\$ 8$ to $\$ 11$ million) as a result of the acquisition, depending on whether we use the 20-day CRSP or four-week SDC premium as the basis for our calculations. Maximum values run into the hundreds of millions of dollars. Data in Table 3 indicate that for the median CEO, the total wealth gains equal roughly six to eight times annual cash compensation (10 to 15 times for the mean CEO). In the context of the high rates of CEO departure described below, these wealth gains appear to represent a rough substitute for the present value of compensation the CEOs might have expected to receive if they had remained in their jobs until retirement, something that we explore further in regression analysis.

\subsection{Stock and option holdings}

The largest source of wealth increase comes from appreciation of the CEO's direct stockholdings, which we calculate by multiplying the percentage acquisition premium by the CEO's pre-announcement equity ownership value. These calculations indicate a median CEO stock appreciation of slightly more than $\$ 1.3$ million, with a much higher mean of about $\$ 4.2$ million.

For appreciation of the CEO's options, data limitations force us to calculate an upper bound; we assume that all options are at- or in-the-money prior to the transaction, and we multiply the raw dollar value premium per share by the number of options held. This calculation assumes that all options are "cashed out" via forced exercise at the time of the transaction, which 
is quite common practice according to our readings of SEC filings. Our analysis shows median and mean option gains of about $\$ 230,000$ and $\$ 656,000$, respectively, only about one-sixth as large as the corresponding statistics for direct stock appreciation.

\subsection{Golden parachutes and related merger payments}

CEOs also obtain significant merger-related wealth increases from golden parachutes and similar payments. Sixty-nine percent of the CEOs in our sample have golden parachute arrangements in place, according to the proxy statements filed in the year prior to the acquisition. The typical structure of these incentive plans calls for a lump-sum payment equal to a multiple of the CEO's salary and bonus prior to the deal (for tax reasons, this multiple equals three in a large number of cases). We calculate the parachute payout to CEOs by applying the formula from each company's golden parachute plan to the CEO's cash salary and bonus in the year prior to the deal..$^{\text {B }}$ Including the 31 percent of observations with zero parachute payments, CEOs receive a median of $\$ 900,000$ (mean of $\$ 1.465$ million) from this source.

For a non-trivial fraction of the CEOs in our sample, 12.1 percent, the parachute payments are augmented by the target's board of directors at the time that it approves the merger. In these cases, boards vote to increase the CEO's parachute value and shareholders learn of the

\footnotetext{
${ }^{3}$ This calculation simplifies the data in two respects. First, some parachute payouts are based on cash compensation not in the year prior to the transaction, but instead according to a more elaborate formula such as the maximum for the three years prior to the transaction. The diversity of these approaches would make our calculations prohibitively complex, so we use the final year's compensation to keep the analysis manageable. Second, we make an assumption that all parachutes are actually triggered by the mergers and acquisitions in our sample. This may not be strictly true if certain deals do not qualify as "changes in control" necessary to activate the parachutes. However, we do not have enough information to make this determination conclusively for many transactions, and we observe that in a large number of SEC merger filings that companies go out of their way to resolve any ambiguity by stipulating that a change in control has occurred for purposes of golden parachute payments. Our treatment of parachute payments in this way means that our estimates probably represent upper bound on the amount that CEOs actually obtain.
} 
change after the fact from an SEC filing. The mean value of the CEO wealth increase from this source is about $\$ 393,500$; dividing this figure by the frequency of .121 indicates that when boards do vote to augment the CEO's parachute, the average value increase is about $\$ 3.25$ million.

Separately from golden parachute payments, some firms make special cash payments to their CEOs as part of the terms of the merger. We find these additional payments in 74 of 272 cases, or about 27.2 percent of the sample. The mean CEO wealth increase from this source is about $\$ 1.2$ million; dividing by the frequency of .272 indicates that the average special merger bonus equals $\$ 4.41$ million. We collect information about firms' stated rationales for these additional payments to CEOs. Twenty-eight cases purportedly represent consulting agreements, and 26 more payments are characterized as non-competition agreements between the CEO and the buyer. An additional 11 cases represent payments made in consideration of the cancellation of the CEO's employment agreement or other contract rights. Other payouts are described as a "stay bonus" (5 observations), "retention bonus" (3), "special service recognition bonus," "signing bonus," and "bonus" ( 2 each), and "transition bonus," "closing bonus," and constructive change-in-control bonus (1 each).

\subsection{Comparison of CEO financial gains with earlier studies}

Our analysis of CEO financial benefits from acquisitions can be contrasted with information from three papers studying takeovers in earlier periods. Cotter and Zenner's (1994) study of managerial resistance to tender offers includes a subsample of 99 completed acquisitions in 1989-90. Firms in their subsample are not directly comparable to ours, as they have much 
smaller mean market cap of $\$ 663$ million. The characteristics of the acquisitions are also quite different, with a significant number of hostile transactions (36 percent) and much larger takeover premia (a mean of 65 percent). The authors report that the top executive in these acquired companies obtains gains on stock and option holdings with a mean value of $\$ 14.1$ million, and golden parachute payments with a mean of $\$ 0.9$ million, numbers that are quite close to our results. While these CEOs run smaller firms, they own significantly more stock (a mean of 7.5 percent of shares outstanding) than our sample CEOs; this ownership level combined with the larger premia received make their financial gains comparable to those in our study. Cotter and Zenner's executives earn mean cash compensation of $\$ 496,000$ annually, meaning that their merger gains are approximately 30 times annual pay, a larger multiple than found for our CEOs. Walkling and Long (1984) also study managerial resistance in a sample of 95 tender offers between 1972-77. Unfortunately, their paper does not disaggregate managerial wealth effects based upon the success of the offers, but their earlier sample exhibits far lower financial gains for CEOs. The authors find an average wealth change for the top-ranked executive from stock and option appreciation of $\$ 713,750$ for uncontested offers and $\$ 192,000$ ( $\$ 161,210)$ for contested, or $\$ 505,050$ for the unified sample. This gain represents an average of 8.6 times the annual salary of these managers.

Agrawal and Walkling (1994) detail severance payments for 13 target CEOs who appeared to leave involuntarily following a takeover bid. For this much smaller sample, their average estimated payments are similar to ours, but their sample does not have large outliers similar to the ones we find. They estimate an average present value for these payments of about \$2.3 million (including parachutes, consulting contracts, etc.). This is roughly in line with our 
estimated average parachute of $\$ 2.7$ million for those CEOs who did have a parachute in place. Including the average additional bonus of $\$ 1.2$ million makes our estimates $70 \%$ larger than those of Agrawal and Walkling, but inflation over the 10-year period between samples and differences in approximation methods could easily account for that gap.

\subsection{Target CEO's subsequent role with the buyer}

In addition to the impact of an acquisition on their personal wealth, CEOs might agree to the sale of their firms because of the prospect of an important position as an executive in the merged company.

More than half of the target CEOs in our sample initially remain with the buyer in some capacity. Panel B of Table 3 indicates that just over 50 percent of target CEOs accept jobs as officers of the merged firm (including non-executive chairman and vice chairman of the board), similar to the acquisition-related turnover data reported by Hadlock at al. (1999) and Martin and McConnell (1991). Additionally, 57 percent of target CEOs join the board of directors of the buyer. This is notably higher than the survival of CEOs as directors documented by Harford (2000), who finds that 27 percent of CEOs are retained. This may be due in part to the greater incidence of hostility in Harford's sample; 26 percent of his observations are classified as hostile compared to the less than three percent of bids that are unsolicited in our sample. A small number of the target CEOs play top leadership roles in the merged firm: nine take over the buyer's CEO position, 15 serve as president and/or chief operating officer, and ten become nonexecutive chairman of the board.

Further data in Panel B indicate that target firms obtain additional governance-related 
considerations. Targets place a median of two directors (mean of 2.3) on the board of the buyer, one of whom is usually but not always the target's CEO. The buyer's board is controlled onesixth by directors from the target subsequent to the median transaction. In about one-seventh of all transactions, the buyer agrees to change the company name, generally to incorporate part of the target's name.

Table 4 presents information about the fate of CEOs who remain with the buyer. Compensation becomes higher for these executives, as their salaries rise by a median of 8.6 percent (mean of 17.6 percent) and their bonuses increase by a median of 19.4 percent (mean of 34.3 percent). While these changes are lower than the 49.1 percent average change in salary plus bonus observed for target CEOs in the 1980s by Agrawal and Walkling (1994), their matching sample of non-target firms experienced a 44.9 percent increase. Agrawal and Walkling also use a slightly longer window of time, from two years before the bid to one year after.

Although the revisions in salary and bonus look fairly good for target CEOs, the survival rates for these executives are strikingly low. We read the first proxy statement filed by the buyer in the aftermath of the merger to determine whether target CEOs who had taken a position in the merged firm are still in place. After one year, the fraction of target CEOs serving as executives of the buyer drops from .503 to .349 , meaning that only 67.1 percent of ex-CEOs survive their first year in office as an executive of the target.

Panel B of Table 4 presents more detailed data about the survival rates of target CEOs who become executives of the parent. We separate these officers into four gradations: (a) CEO, president, and chairman; (b) other executive officers; (c) executives in subsidiaries of the buyer (such as CEOs who remain as CEOs of the target once it becomes wholly owned by the buyer); 
and (d) vice chairman of the board, a title that usually carries little or no operating responsibility. We extend our analysis by reading proxy statements filed for the three years after the acquisition. ${ }^{9}$ All categories of executives have extremely high departure rates. First-year departure rates range from 23.1 percent for officers in the top-three category to 59.3 percent for vice chairmen. After three years, 67.3 percent of top-three officers and 88.2 percent of subsidiary executives are gone, and departure rates are similarly high for vice chairmen and executives in other positions.

Data are similar but not quite as dramatic for ex-CEOs serving on boards, as just 77.6 percent of this group remain as directors after 1 year.

These turnover rates far exceed those found in most studies of CEOs and corporate directors. For comparison purposes, Parrino (1997) reports unconditional turnover rates for CEOs of 12.2 percent annually, while data in Shivdasani and Yermack (1999) indicate an unconditional turnover rate for directors of about 9 percent annually. Our results are more in line with Gilson's (1990) presentation of very low survival rates for officers and directors in financially distressed firms.

Some of the ex-CEOs who do not survive as executives of the buyer collect substantial severance packages (these do not enter into our calculation of merger-related wealth changes discussed above). Of the 146 ex-CEOs whom we identify as becoming executives of the buyer, 48 are no longer listed as executives in the first proxy statement filed after the transaction. Of these 48,37 collect severance payments with a median value of $\$ 1.5$ million, mean of $\$ 3.77$

\footnotetext{
${ }^{4}$ A certain number of companies disappear from our analysis because the buyer itself is acquired by a third firm.
} 
million, and maximum of $\$ 30$ million.

One reason for the high turnover rates of target CEOs after they join the buyer is that some of their appointments are made with pre-specified limited time horizons. We find 18 such cases out of the 146 CEOs who become executives of the buyer, a rate of about 12 percent. The life of these agreements range from a few months (until the next annual meeting) to five years.

We find that some target CEOs negotiate explicit succession agreements to secure their positions in the new firm, but these agreements are generally not honored. In four cases, the target CEO becomes the CEO of the buyer but is required to surrender the job within a specified period; in three additional cases, the target CEO becomes chairman and chief operating officer of the buyer, with the stipulation that he will ascend to the CEO position within a certain period. In only one instance of these seven (the merger of Nynex and Bell Atlantic) did the CEO position ultimately change hands as called for in the original agreement. In two further cases the agreement arguably became moot, as one controversial CEO was prevented by government utility regulators from taking office, and another negotiated the sale of the firm before the date at which he was due to step down.

\subsection{Regression analysis}

When CEOs bargain with the acquiror over acquisition terms that affect them personally, we conjecture that they engage in tradeoffs between cash payments, their position in the merged company, board seats, and other personal benefits. We expect that these tradeoffs are influenced by personal characteristics of CEOs, especially age (a proxy for the time left until expected retirement) and the extent to which they dominate the corporate governance of the target firm. 
A second set of more nefarious tradeoffs may also exist. Target CEOs might be expected to sell the firm at an attractive price if their personal benefits from the transaction are large. Since a low takeover premium for target shareholders would also depress the CEO's own stock and option appreciation, we might expect CEOs to accept lower takeover premia only if they receive prominent jobs in the management of the buyer or special compensation arrangements not directly related to equity value.

We conduct regression analysis in an attempt to illuminate the relative magnitude of some of these tradeoffs. Our regressions test several hypotheses about patterns in which we expect CEOs to seek to extract private benefits from the buyer:

1. CEOs who do not become officers of the acquiror should obtain greater monetary gains from the acquisition, since they effectively surrender the permanent income stream associated with their former positions.

2. CEO financial gains should be inversely related to the prominence of the CEO's new position in the buyer, if any.

3. Older CEOs should extract lower monetary benefits, since the present value of the lifetime income stream they surrender is lower.

4. CEOs with greater bargaining power should obtain greater personal benefits. We measure bargaining power in two ways: (i) the ratio of the market capitalization of the target relative to that of the buyer; and (ii) the percentage equity ownership of the target CEO in his own firm.

5. CEOs who do become top officers of the acquiror or receive other forms of favorable treatment should be expected to agree to transactions with lower prices paid to target shareholders.

Tables 5, 6 and 7 present results of OLS regressions that test these hypotheses. In Table 5, the dependent variable for the model in the first column equals the total monetary gains from all sources, including stock and option appreciation, golden parachutes, augmented parachutes, 
and additional deal bonuses. Explanatory variables include dummy variables for whether the CEO becomes an officer or director of the target, CEO age, the market capitalization of the target, the ratio between the target's and buyer's market caps, and the percentage ownership of the target CEO. The right column shows the same model, but with the dependent variable equal to direct cash payments to the CEO, excluding stock and option appreciation. We find evidence that the CEO's total monetary gains are lower when he becomes an officer of the target, with an estimate of $-\$ 4.3$ million that is significant at the 5 percent level. However, the estimate falls to $\$ 1.1$ million and loses significance when the dependent variable is restricted to cash compensation only.

In Table 6, we repeat the analysis from Table 5 but replace the officer dummy variable with four dummies indicating different levels of responsibility: (i) the CEO takes a "top three" post of CEO, president, or chairman; (ii) the CEO takes another executive position in top management, such as executive or senior vice president; (iii) the CEO becomes vice chairman of the board with no direct management responsibility; and (iv) the CEO becomes an officer of a division of the buyer (usually his old firm, which becomes a wholly owned subsidiary). The coefficient estimates on these dummy variables are rank-ordered in an intuitive way. CEOs who move into top positions in the buyer appear to forego the largest financial gains from the merger transaction, a result that makes sense since one expects them to earn the greatest future compensation from their new posts. Other executive officers sacrifice the second-most pay, followed by vice chairmen and subsidiary officers.

Our regression estimates of an inverse association between monetary gains and postmerger executive positions do not extend to directorships. Results in Table 5 indicate a weakly 
positive but insignificant association between target CEOs' financial gains and a dummy variable for whether they join the board of directors of the buyer.

We do not find the expected relation between CEO age and monetary benefits. In every specification of both tables, we estimate a positive and significant coefficient on the age variable, indicating the older CEOs extract greater financial gains from the merger transaction. Although older CEOs are sacrificing less future income by selling their firms, one might understand the regression estimates in several ways. Older CEOs might have greater tenure and influence over corporate governance, meaning that the age variable serves as a proxy for bargaining power. Older CEOs might also have accumulated more stock and options in their firms.

Further indications of CEO bargaining power have coefficient estimates clearly in line with our hypotheses. CEOs who own more stock, and CEOs from firms whose relative size is closer to the size of the buyer both succeed in extracting greater financial gains, according to estimates in both models, although the CEO stock ownership result loses significance in the model shown in the right column.

Table 7 explores the relation between personal benefits received by target CEOs and the acquisition premia paid to their shareholders. We focus on benefits indicating extraordinary treatment of the CEO, and we deliberately omit appreciation of the CEO's stock and option holdings, since these gains will exhibit a lock-step positive association with the premium paid to all shareholders. Our main independent variables, used in the model in the first column of Table 7, are dummy variables for (i) whether the CEO's golden parachute is augmented at the time of the transaction; (ii) whether the CEO received additional merger-related payments such as consulting contracts or special bonuses; (iii) - (vi) four dummies indicating the level of executive 
position, if any, obtained by the CEO in the buyer; and (vii) whether the CEO joins the board of directors of the buyer.

As shown in the first column of Table 7, all seven of the dummy variables for CEO personal benefits have negative coefficient estimates, though all of these estimates are insignificant. The negative coefficients are consistent with a conjecture that CEOs negotiate less favorable acquisition terms for their own shareholders when the transaction includes special treatment of the CEO. In the center column of Table 7, we estimate the same model but add together the seven dummy variables. The coefficient on the sum of these dummies - equivalent to an F-based hypothesis test of whether their sum is significantly different from zero - has a negative estimate, significant at the 10 percent level. Finally, in the right column of Table 7, we repeat this analysis but restrict ourselves to the subsample of CEOs who own less than the median amount of equity ( $\$ 12.15$ million) in their firms. We expect this group to be more predisposed in merger negotiations to trade off equity appreciation for personal benefits, since they stand to lose less financially than CEOs with greater ownership. With the regression limited to this subsample, the coefficient estimate for the sum of the seven dummy variables grows in magnitude by about 50 percent and becomes significant at the 5 percent level.

\section{Conclusions}

We study the private benefits obtained by target company CEOs in successful merger and acquisition transactions. Our research is motivated by frequent news reports of large agency conflicts in M\&A bargaining situations.

The magnitude of the CEO wealth increases that we document appear roughly in line with 
the permanent income streams that they sacrifice by selling their firms. We find that target CEOs obtain wealth increases with a median of $\$ 4$ to $\$ 5$ million and a mean of $\$ 8$ to $\$ 11$ million. These financial benefits arise mostly from stock and option appreciation, though a majority of CEOs also receive substantial golden parachute payments. Some CEOs receive last-minute financial benefits when their boards of directors vote to approve mergers, as 12 percent have their golden parachutes increased and 28 percent receive a variety of additional cash bonuses. The extra payments, when made, typically add millions of dollars to the CEO's merger gains. Regression analysis indicates an inverse association between the CEO's monetary benefits and their new status (if any) in the merged firm. About half of the target CEOs in our sample become officers of the buyer, with a handful ascending into top management positions. While these executives receive higher compensation than before, we find that their new positions are hazardous, with extremely high departure rates in the three years following completion of the transaction. A large majority of those executives who do lose their new jobs are compensated through large severance payments.

We explore whether CEOs compromise the interests of their shareholders in those transactions in which they receive extraordinary personal benefits. Regression results provide some evidence of an inverse association between selling shareholder premia and such CEO benefits as positions in the buyer and unusual financial bonuses awarded at the time of the transaction. 


\section{References}

Agrawal, Anup, and Ralph A. Walkling, 1994, Executive careers and compensation surrounding takeover bids, Journal of Finance 49, 985-1014.

Berkovitch, Elazar and Ronen Israel, 1996, The design of internal control and capital structure, Review of Financial Studies 9, 209-240.

Burton, Thomas M. and Elyse Tanouye, 1998, Another drug industry megamerger goes bust, The Wall Street Journal, October 13.

Cotter, James F. and Marc Zenner, 1994, How managerial wealth affects the tender offer process, Journal of Financial Economics 35, 63-97.

Fama, Eugene, 1980, Agency problems and the theory of the firm, Journal of Political Economy 88, 288-307.

Fluck, Zsuzsanna, 1999, The dynamics of the management-shareholder conflict, Review of Financial Studies 12, 379-404.

Gilson, Stuart C., 1990, Bankruptcy, boards, banks and blockholders: Evidence on changes in corporate ownership and control when firms default, Journal of Financial Economics 27, 355387.

Hadlock, Charles, Joel Houston, and Michael Ryngaert, 1999, The role of managerial incentives in bank acquisitions, Journal of Banking and Finance 23, 221-249.

Harford, Jarrad, 2000, Takeover bids and target directors' incentives: Retention, experience, and settling up, University of Oregon working paper.

Hechinger, John, 1999, BankBoston's CEO got safeguards in Fleet buyout, The Wall Street Journal, March 17.

Lipin, Steven, 1996, In many merger deals, ego and pride play big roles in which way talks go, The Wall Street Journal, August 22.

Martin, Kenneth J. and John J. McConnell, 1991, Corporate performance, corporate takeovers, and management turnover, Journal of Finance 46, 671-687.

Mikkelson, Wayne H. and M. Megan Partch, 1989, Managers' voting rights and corporate control, Journal of Financial Economics 25, 263-290.

Mørck, Randall, Andrei Shleifer, and Robert W. Vishny, 1988, Characteristics of targets of hostile and friendly takeovers, in Alan J. Auerbach ed., Corporate takeovers: Causes and consequences, University of Chicago Press, Chicago, IL. 
Palepu, Krishna G., 1986, Predicting takeover targets: A methodological and empirical analysis, Journal of Accounting and Economics 8, 3-35.

Parrino, Robert, 1977, CEO turnover and outside succession: A cross-sectional analysis, Journal of Financial Economics 46, 165-197.

Salpukas, Agis, 1999, Texaco rejects Chevron's merger proposal, The New York Times, June 3.

Schwert, G. William, 2000, Hostility in takeovers: In the eyes of the beholder? Journal of Finance, forthcoming.

Shivdasani, Anil, 1993, Board composition, ownership structure, and hostile takeovers, Journal of Accounting and Economics 16, 167-198.

Shivdasani, Anil and David Yermack, 1999, CEO involvement in the selection of new board members: An empirical analysis, Journal of Finance 54, 1829-1853.

Stulz, René, 1988, Managerial control of voting rights: Financing policies and the market for corporate control, Journal of Financial Economics 20, 25-54.

Walkling, Ralph A. and Michael S. Long, 1984, Agency theory, managerial welfare and takeover bid resistance, RAND Journal of Economics 15, 54-68. 
Table 1

Characteristics of CEOs of acquired companies

Descriptive statistics about the ownership, compensation, and other characteristics of CEOs of acquired companies. The sample includes 311 large firms acquired between 1995 and 1997. Information is obtained from proxy statements filed during the last year prior to the transaction. The dummy variables for separate chairman and separate president equal one if a person other than the CEO serves in these positions.

\begin{tabular}{lcccc}
\hline \hline Variable & Mean & Median & Max & Obs \\
\hline CEO shares/shares outstanding & 0.036 & 0.008 & 0.506 & 285 \\
CEO total options/shares outstanding & 0.016 & 0.011 & 0.211 & 285 \\
CEO salary prior to acquisition & 423,322 & 351,489 & $2,493,795$ & 289 \\
CEO bonus prior to acquisition & 374,559 & 170,000 & $5,965,313$ & 289 \\
CEO age & 53.886 & 54.000 & 74.000 & 290 \\
CEO tenure less than 5 years dummy & 0.496 & 0.000 & 1.000 & 290 \\
Separate president dummy & 0.285 & 0.000 & 1.000 & 298 \\
Separate chairman dummy & 0.305 & 0.000 & 1.000 & 298 \\
\hline
\end{tabular}


Table 2

Transaction characteristics

Descriptive statistics about the acquisitions of 311 large firms between 1995 and 1997. Information is obtained from databases maintained by Securities Data Corporation and the Center for Research in Securities Prices. The value of target and buyer firms is measured one month prior to the date of the first offer. The premium received by target shareholders is calculated relative to the transaction announcement date. SDC premium calculations assume that the transaction is completed according to terms announced in the merger agreement. CRSP premium calculations are based on actual market prices of the target's stock.

\begin{tabular}{lcccc}
\hline \hline Variable & Mean & Median & Max & Obs \\
\hline & & & & \\
Target value prior to the offer (000) & $1,267,330$ & 385,680 & $21,445,802$ & 309 \\
Buyer value prior to the offer (000) & $3,344,627$ & $1,279,235$ & $51,196,340$ & 309 \\
Target value/buyer value & 0.442 & 0.317 & 3.020 & 309 \\
Unsolicited dummy & 0.026 & 0.000 & 1.000 & 309 \\
Total premium four weeks, SDC data & 0.348 & 0.304 & 1.259 & 308 \\
Stock return, two days, CRSP data & 0.155 & 0.137 & 0.854 & 309 \\
Stock return, 20 days, CRSP data & 0.227 & 0.211 & 1.412 & 309 \\
\hline
\end{tabular}


Table 3

Gains received by target CEOs

Wealth increases and governance considerations obtained by the CEOs of target firms. The sample includes 311 large firms acquired between 1995 and 1997. Information is obtained from Form S-4 or similar documents filed with the SEC at the time of the acquisition. Gains in the value of CEO stock holdings are computed using four-week premiums as measured by both the SDC and CRSP databases. Option gains are calculated similarly using an assumption that all options are at- or in-the-money prior to the transaction. Golden parachute payments are calculated based on information from the target company's last proxy statement filed prior to the transaction. Augmented parachutes and deal bonuses represent additional payments awarded to CEOs at the time of the acquisition.

Panel A: Monetary gains

\begin{tabular}{lcccc}
\hline \hline Variable & Mean & Median & Max & Obs \\
\hline Stock gains & & & & \\
Share gains (use 20 day CRSP return) & $4,247,863$ & $1,338,146$ & $129,100,000$ & 290 \\
Option gains (use 20 CRSP return) & 656,451 & 229,908 & $8,267,318$ & 283 \\
& & & & \\
Cash compensation & & & & \\
Parachute & $1,465,251$ & 900,000 & $24,976,764$ & 277 \\
Augmentation of parachute & 393,545 & 0 & $36,944,986$ & 272 \\
Additional bonus & $1,201,011$ & 0 & $60,000,000$ & 272 \\
Parachute dummy & 0.690 & 1.000 & 1.000 & 277 \\
Augmentation of parachute dummy & 0.121 & 0.000 & 1.000 & 272 \\
Additional bonus dummy & 0.279 & 0.000 & 1.000 & 272 \\
& & & & \\
Total gains & & & & \\
Total gains (20 day CRSP stock return) & $8,117,406$ & $3,830,462$ & $132,360,000$ & 243 \\
Total gains (four week SDC premium) & $11,767,526$ & $5,320,657$ & $217,750,000$ & 242 \\
Total gains/Salary+bonus (20 day return) & 10.175 & 6.440 & 118.200 & 242 \\
Total gains/Salary+bonus (four week premium) & 15.956 & 8.789 & 200.370 & 241 \\
\hline
\end{tabular}

Panel B: Other gains

\begin{tabular}{lcccc}
\hline \hline Variable & Mean & Median & Max & Obs \\
\hline & & & & \\
CEO remains as officer & 0.503 & 1.000 & 1.000 & 290 \\
CEO remains as director & 0.571 & 1.000 & 1.000 & 289 \\
Number of target members on new board & 2.314 & 2.000 & 15.000 & 287 \\
Target board members/new buyer board size & 0.176 & 0.167 & 0.545 & 285 \\
Buyer changes name & 0.147 & 0.000 & 1.000 & 279 \\
\hline
\end{tabular}


Table 4

Status of target CEOs who become officers and directors of the buyer

Compensation and subsequent employment status of CEOs of target firms who accept positions with the acquiror. The sample includes 311 large firms acquired between 1995 and 1997. Information is obtained from Proxy Statements filed with the SEC for the three years following the acquisition.

$$
\text { Panel A: CEO status }
$$

\begin{tabular}{lcccc}
\hline \hline Variable & Mean & Med & Max & Obs \\
\hline & & & & \\
CEO remains as officer after 1 year & 0.349 & 0.000 & 1.000 & 281 \\
Frequency of CEO surviving 1 year as officer & 0.671 & 1.000 & 1.000 & 167 \\
CEO remains as director after 1 year & 0.451 & 0.000 & 1.000 & 293 \\
Frequency of CEO surviving 1 year as director & 0.776 & 1.000 & 1.000 & 165 \\
Change in CEO salary & 1.176 & 1.086 & 6.752 & 98 \\
Change in CEO bonus & 1.343 & 1.194 & 4.982 & 83 \\
CEO receiving severance in year 1 dummy & 0.132 & 0.000 & 1.000 & 281 \\
Severance paid in year 1 & $3,770,864$ & $1,500,000$ & $30,000,000$ & 37 \\
\hline
\end{tabular}

Panel B: Departure rate by CEO new position at new firm

\begin{tabular}{lcccc}
\hline \hline & \multicolumn{3}{c}{ Cumulative departure rate of target CEO } & \\
New position after the merger & One year & Two years & Three years & Obs \\
\hline CEO, President, Chairman & 0.231 & 0.495 & 0.673 & 52 \\
Other executive officer & 0.333 & 0.500 & 0.700 & 21 \\
Executive in a subsidiary & 0.283 & 0.686 & 0.882 & 46 \\
Vice chairman & 0.593 & 0.715 & 0.857 & 27 \\
\hline
\end{tabular}




\section{Table 5}

CEO monetary gains and offer characteristics

Ordinary least squares estimates of monetary gains obtained by CEOs in a sample of 311 large firms acquired between 1995 and 1997. The dependent variable in the left column includes gains from equity appreciation, option appreciation, golden parachutes, augmented parachutes, and additional merger-related bonuses. The dependent variable in the right column includes gains from parachutes and bonuses only. The market capitalization of target and buyer firms is measured one month prior to the first offer made by the buyer. Data is obtained from Proxy Statements, Forms S-4, and similar SEC filings.

\begin{tabular}{lcc}
\hline \hline & Merger gains, total & Merger gains, cash \\
\hline Intercept & $-22,553,581^{a}$ & $-4,791,037$ \\
& $(3.13)$ & $(1.38)$ \\
Target CEO remains as an officer & $-4,307,095^{b}$ & $-1,194,799$ \\
& $(2.04)$ & $(1.18)$ \\
Target CEO remains as director & $1,671,447$ & 479,463 \\
& $(0.78)$ & $(0.47)$ \\
CEO age & $471,392^{a}$ & $112,496^{c}$ \\
& $(3.69)$ & $(1.83)$ \\
Target value prior to acquisition & $3,709,726$ & $1,910,636$ \\
& $(1.45)$ & $(1.55)$ \\
Target value/buyer value & $1.81^{a}$ & $0.96^{a}$ \\
& $(5.37)$ & $(5.91)$ \\
CEO shares/shares outstanding & $71,889,874^{a}$ & $2,830,192$ \\
Observations & $(5.73)$ & $(0.47)$ \\
Adj $\mathrm{R}^{2}$ & 239 & 239 \\
\hline
\end{tabular}

a,b,c denotes significantly different from zero at the 1, 5, and 10 percent levels. 
Table 6

CEO monetary gains

Ordinary least squares estimates of monetary gains obtained by CEOs in a sample of 311 large firms acquired between 1995 and 1997. The dependent variable in the left column includes gains from equity appreciation, option appreciation, golden parachutes, augmented parachutes, and additional merger-related bonuses. The dependent variable in the right column includes gains from parachutes and bonuses only. The market capitalization of target and buyer firms is measured one month prior to the first offer made by the buyer. Data is obtained from Proxy Statements, Forms S-4, and similar SEC filings.

\begin{tabular}{|c|c|c|}
\hline & Merger gains, total & Merger gains, cash \\
\hline Intercept & $\begin{array}{c}-21,736,625^{a} \\
(2.97)\end{array}$ & $\begin{array}{c}-4,549,732 \\
(1.30)\end{array}$ \\
\hline Target CEO remains in top 3 position & $\begin{array}{c}-5,255,090^{b} \\
(2.07)\end{array}$ & $\begin{array}{c}-2,315,530^{c} \\
(1.91)\end{array}$ \\
\hline Target CEO remains executive officer & $\begin{array}{c}-5,076,593 \\
(1.51)\end{array}$ & $\begin{array}{c}-1,334,105 \\
(0.83)\end{array}$ \\
\hline Target CEO remains as vice chairman & $\begin{array}{c}-2,543,589 \\
(0.76)\end{array}$ & $\begin{array}{c}741,682 \\
(0.46)\end{array}$ \\
\hline Target CEO remains as officer of subsidiary & $\begin{array}{c}-1,819,060 \\
(0.74)\end{array}$ & $\begin{array}{c}-336,339 \\
(0.29)\end{array}$ \\
\hline CEO age & $\begin{array}{c}460,970^{a} \\
(3.55)\end{array}$ & $\begin{array}{c}107,406^{c} \\
(1.73)\end{array}$ \\
\hline Target value prior to acquisition & $\begin{array}{c}4,377,523^{c} \\
\quad(1.70)\end{array}$ & $\begin{array}{c}2,325,385^{c} \\
\quad(1.89)\end{array}$ \\
\hline Target value/buyer value & $\begin{array}{l}1.90^{a} \\
(5.46)\end{array}$ & $\begin{array}{l}0.99^{a} \\
(5.99)\end{array}$ \\
\hline CEO shares/shares outstanding & $\begin{array}{c}70,569,716^{a} \\
(5.62)\end{array}$ & $\begin{array}{c}2,292,804 \\
(0.38)\end{array}$ \\
\hline $\begin{array}{l}\text { Observations } \\
\text { Adj } R^{2}\end{array}$ & $\begin{array}{c}241 \\
0.243\end{array}$ & $\begin{array}{c}241 \\
0.166\end{array}$ \\
\hline
\end{tabular}

a,b,c denotes significantly different from zero at the 1, 5, and 10 percent levels. 
Table 7

Trade off between CEO gains and shareholders premuim

Ordinary least squares estimates of shareholder's stock premuim in a sample of 311 large firms acquired between 1995 and 1997. The dependent variable is equals the return to target shareholders over the 20-day period up to and including the acquisition announcement date. Regressions in the left and middle columns includes then entire sample. Regression in the right columns include the subsample where the total value of shares and options held by the CEO is below the sample median $\$ 12.15$ million.

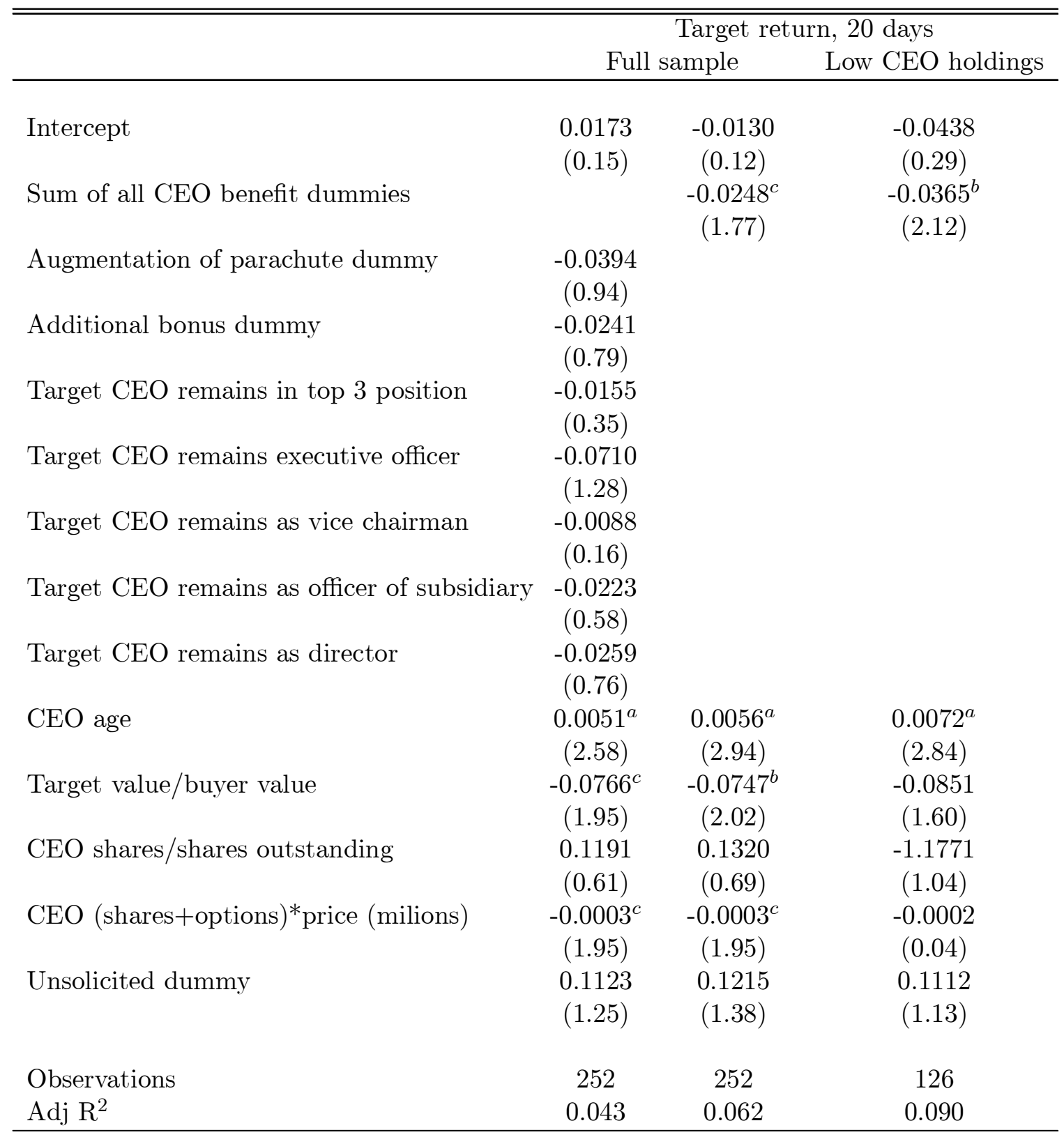

a,b,c denotes significantly different from zero at the 1, 5, and 10 percent levels. 